\title{
Network Global Navigation Satellite System Surveys To Harmonize American and Canadian Datums for the Lake Champlain Basin
}

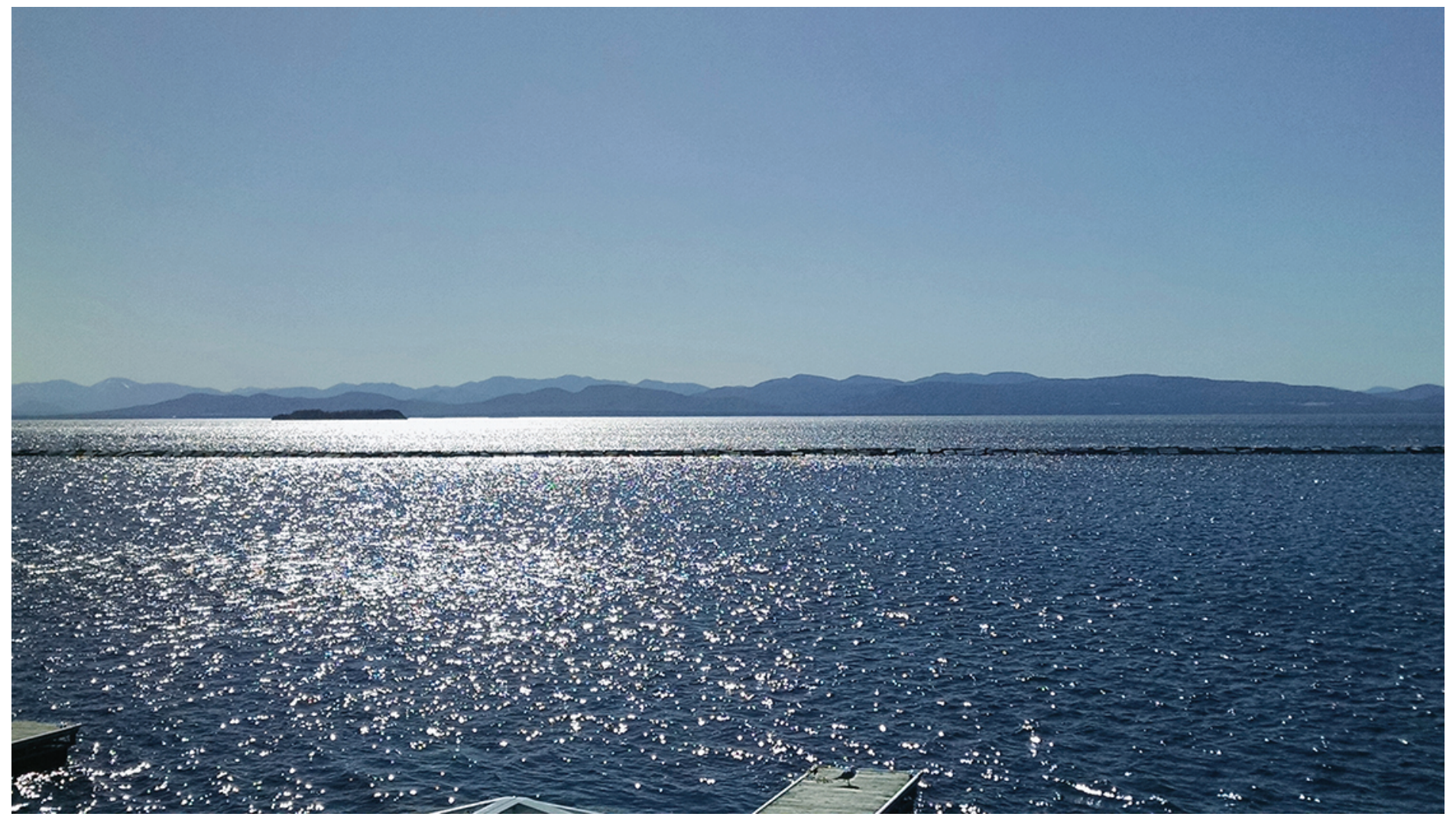

Scientific Investigations Report 2016-5009

Version 1.1, April 2016

U.S. Department of the Interior

U.S. Geological Survey 
Cover. Lake Champlain from Burlington, Vermont. Photograph by John Erbland, U.S. Geological Survey. 


\section{Network Global Navigation Satellite System Surveys To Harmonize American and Canadian Datums for the Lake Champlain Basin}

By Robert H. Flynn, Paul H. Rydlund, Jr., and Daniel J. Martin

Prepared in cooperation with the International Joint Commission

Scientific Investigations Report 2016-5009

Version 1.1, April 2016 


\title{
U.S. Department of the Interior SALLY JEWELL, Secretary
}

\section{U.S. Geological Survey Suzette M. Kimball, Director}

\author{
U.S. Geological Survey, Reston, Virginia \\ First release: 2016 \\ Revised: April 2016 (ver. 1.1)
}

For more information on the USGS —-the Federal source for science about the Earth, its natural and living resources, natural hazards, and the environment-visit http://www.usgs.gov/ or call 1-888-ASK-USGS.

For an overview of USGS information products, including maps, imagery, and publications, visit http://www.usgs.gov/pubprod/.

Any use of trade, firm, or product names is for descriptive purposes only and does not imply endorsement by the U.S. Government.

Although this information product, for the most part, is in the public domain, it also may contain copyrighted materials as noted in the text. Permission to reproduce copyrighted items must be secured from the copyright owner.

Suggested citation:

Flynn, R.H., Rydlund, P.H., Jr., and Martin, D.J., 2016, Network global navigation satellite system surveys to harmonize American and Canadian datums for the Lake Champlain Basin (ver. 1.1, April 2016): U.S. Geological Survey Scientific Investigations Report 2016-5009, 17 p., http://dx.doi.org/10.3133/sir20165009.

ISSN 2328-0328 (online) 


\section{Acknowledgments}

The authors wish to thank the International Joint Commission for funding the Lake Champlain Basin datum harmonization study and members of the International Lake Champlain-Richelieu River Technical Working Group (TWG), Pierre-Yves Caux (International Joint Commission), Paul Boudreau of Environment Canada, Marc Véronneau (Natural Resources Canada, Canadian Geodetic Survey) and Joe Babb (U.S. Department of State, detail assignment to International Joint Commission) for their role in determining the scope and design of this study. Members of the TWG include the following: Jean-François Cantin (Environment Canada and Canadian cochair of the TWG ), Richard Turcotte (Quebec Ministry of Sustainable Development, Environment, and Parks), William Saunders (National Weather Service), Vincent Fortin (Environment Canada), Daniel LeBlanc (Quebec Ministry of Sustainable Development, Environment, and Parks), Blaine Hastings (Vermont Department of Environmental Conservation), and Fred Dunlap (New York State Department of Environmental Conservation).

The authors wish to thank Guy Morin and Julie Thérien (Environment Canada) for providing reference mark and elevation data in Canada and for all of their help in locating and gaining access permission for the Global Navigation Satellite System (GNSS) surveys in the Lake Champlain Basin in Canada.

The authors would also like to thank Madeleine Papineau (International Joint Commission) and Stephanie Castle (Lake Champlain Basin Program) for administrative and secretarial support for this project.

The authors wish to thank Keith Robinson (U.S. Geological Survey [USGS] and American cochair of the TWG) and the following USGS personnel for their efforts in collecting GNSS survey data from April 14-16, 2015: Ann Chalmers, John "Duke" Erbland, Jonathan Graham, Doug Nagle, and Glenn Berwick. 



\section{Contents}

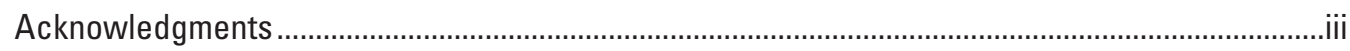

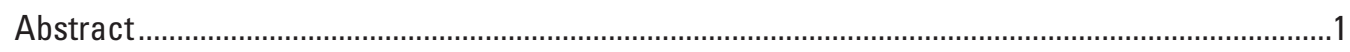

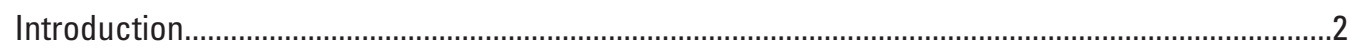

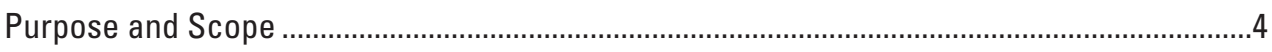

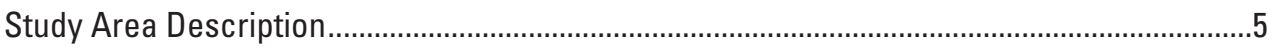

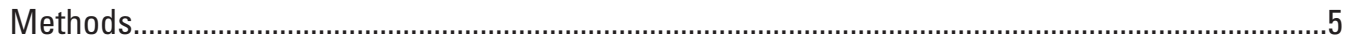

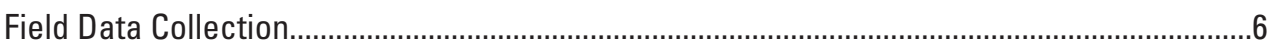

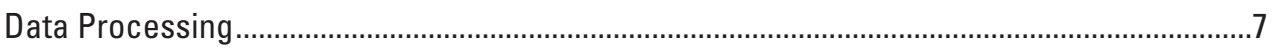

Gage Datum Offsets.........................................................................................................

GNSS Survey Harmonization Results .........................................................................................

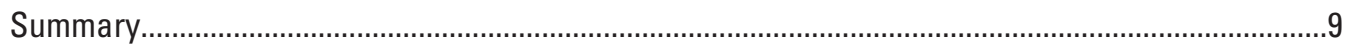

References Cited...............................................................................................................10

Appendix 1. Global Navigation Satellite System Data Collection Information for All

Benchmarks Surveyed in the Harmonization of American and Canadian Datums.............14

Appendix 2. Final Coordinates as Determined in and From the Online Positioning User

Service Projects Least-Squares Adjustment for Harmonization of the American and

Canadian Datums

Appendix 3. Surveyor Leveling Information for Sites With Benchmarks That Could Not Be Surveyed Directly by Using Global Navigation Satellite Systems in Harmonization of the American and Canadian Datums.

Appendix 4. Elevation Offset Information for Benchmarks Surveyed Directly by Using Global Navigation Satellite Systems in Harmonization of the American and Canadian Datums.

\section{Figures}

1. Map showing Lake Champlain Basin including Global Navigation Satellite System lake gages, streamgages, and dam benchmarks surveyed by the U.S. Geological Survey......

2. Graph showing instantaneous water-surface elevations referenced to the North American Vertical Datum of 1988, from the Global Navigation Satellite System surveys, for the data collection period (Julian days 104-106) at U.S. Geological Survey lake gages in Lake Champlain.

\section{Tables}

1. Lake Champlain and Richelieu River water-level gages and dam benchmarks used in the Global Navigation Satellite System Surveys

2. Global Navigation Satellite System benchmark survey results from Online Positioning User Service Projects network adjustment.

3. Offsets for conversion of published water-surface elevations to the North American Vertical Datum of 1988 for lake gages in Lake Champlain and streamgages in the Richelieu River.... 


\section{Conversion Factors}

Inch/Pound to International System of Units

\begin{tabular}{|c|c|c|}
\hline Multiply & By & To obtain \\
\hline \multicolumn{3}{|c|}{ Length } \\
\hline foot (ft) & 0.3048 & meter (m) \\
\hline mile (mi) & 1.609 & kilometer (km) \\
\hline \multicolumn{3}{|c|}{ Area } \\
\hline square mile $\left(\mathrm{mi}^{2}\right)$ & 2.590 & square kilometers $\left(\mathrm{km}^{2}\right)$ \\
\hline
\end{tabular}

Temperature in degrees Celsius $\left({ }^{\circ} \mathrm{C}\right)$ may be converted to degrees Fahrenheit $\left({ }^{\circ} \mathrm{F}\right)$ as ${ }^{\circ} \mathrm{F}=\left(1.8 \times{ }^{\circ} \mathrm{C}\right)+32$.

\section{Datum}

Vertical coordinate information is referenced to the North American Vertical Datum of 1988 (NAVD 88), the National Geodetic Vertical Datum of 1929 (NGVD 29), the Canadian Geodetic Vertical Datum of 1928 (CGVD 28), and the Canadian Geodetic Vertical Datum of 2013 (CGVD2013).

Horizontal coordinate information is referenced to the North American Datum of 1983 (NAD 83).

Elevation, as used in this report, refers to distance above the vertical datum.

\section{Supplemental Information}

Precipitation is given in inches per year (in/yr). 


\section{Abbreviations}

$\begin{array}{ll}\text { CGG 2013 } & \text { Canadian Gravimetric Geoid model of } 2013 \\ \text { CGS } & \text { Canadian Geodetic Survey } \\ \text { CGVD2013 } & \text { Canadian Geodetic Vertical Datum of } 2013 \\ \text { CGVD 28 } & \text { Canadian Geodetic Vertical Datum of } 1928 \\ \text { CSRS } & \text { Canadian Spatial Reference System } \\ \text { EC } & \text { Environment Canada } \\ \text { GNSS } & \text { Global Navigation Satellite System } \\ \text { IJC } & \text { International Joint Commission } \\ \text { NAD 83 } & \text { North American Datum of 1983 } \\ \text { NAVD 88 } & \text { North American Vertical Datum of } 1988 \\ \text { NGS } & \text { National Geodetic Survey } \\ \text { NGVD 29 } & \text { National Geodetic Vertical Datum of } 1929 \\ \text { NRCan } & \text { Natural Resources Canada } \\ \text { OPUS } & \text { Online Positioning User Service } \\ \text { PPP } & \text { Precise Point Positioning } \\ \text { USGS } & \text { U.S. Geological Survey }\end{array}$





\title{
Network Global Navigation Satellite System Surveys To Harmonize American and Canadian Datums for the Lake Champlain Basin
}

\author{
By Robert H. Flynn, ${ }^{1}$ Paul H. Rydlund, Jr., ${ }^{1}$ and Daniel J. Martin ${ }^{2}$
}

\section{Abstract}

Historically high flood levels were observed during flooding in Lake Champlain and the Richelieu River from late April through May 2011. Flooding was caused by record spring precipitation and snowmelt from the third highest cumulative snowfall year on record, which included a warm, saturated late spring snowpack. Flood stage was exceeded for a total of 67 days from April 13 to June 19, 2011. During this flooding, shoreline erosion and lake flood inundation were exacerbated by wind-driven waves associated with local fetch and lake-wide seiche effects. In May 2011, a new water-surface-elevation record was set for Lake Champlain. Peak lake-level water-surface elevations varied at the three U.S. Geological Survey lake-level gages on Lake Champlain in 2011. The May 2011 peak water-surface elevations for Lake Champlain ranged from 103.20 feet above the National Geodetic Vertical Datum of 1929 at the northern end of Lake Champlain (at its outlet into the Richelieu River at Rouses Point, New York) to 103.57 feet above the National Geodetic Vertical Datum of 1929 at the southern end of the Lake in Whitehall, New York. The water-surface elevations for the Richelieu River in Canada are referenced to a different vertical datum than are those in Lake Champlain in the United States, which causes difficulty in assessing real-time flood watersurface elevations and comparing of flood peaks in the Lake Champlain Basin in the United States and Canada.

On March 19, 2012, as a result of the flood event of April and May 2011, the Governments of Canada and the United States asked the International Joint Commission to draft a plan of study to examine the causes and the effects of the spring 2011 flooding on Lake Champlain and the Richelieu River and develop potential mitigation measures. Specific challenges noted by the International Lake Champlain-Richelieu River

\footnotetext{
${ }^{1}$ U.S. Geological Survey.
}

${ }^{2}$ National Oceanic and Atmospheric Administration.
Technical Working Group (established by the International Joint Commission) included harmonization of vertical datums within the drainage basin. Harmonization of the vertical datum discrepancy is needed for flood assessment and future efforts to model the flow of water through the Lake Champlain Basin in the United States and Canada.

In April 2015, the U.S. Geological Survey and Environment Canada began a joint field effort with the goal of obtaining precise elevations representing a common vertical datum for select reference marks used to determine water-surface elevations throughout Lake Champlain and the Richelieu River. To harmonize the datum difference between the United States and Canada, Global Navigation Satellite System surveys were completed at nine locations in the Lake Champlain Basin to collect simultaneous satellite data. These satellite data were processed to produce elevations for two reference marks associated with dams and seven reference marks associated with active water-level gages (lake gages in Lake Champlain and streamgages in the Richelieu River) to harmonize vertical datums throughout the Lake Champlain Basin. The Global Navigation Satellite System surveys were completed from April 14 to 16, 2015, at locations ranging from southern Lake Champlain near Whitehall, New York, to the northern end of the Richelieu River in Sorel, Quebec, at its confluence with the St. Lawrence River in Canada.

Lake-gage water-surface elevations determined during the 3 days of surveys were converted to water-surface elevations referenced to the North American Vertical Datum of 1988 by using calculated offsets and historical water-surface elevations. In this report, an "offset" refers to the adjustment that needs to be applied to published data from a particular gage to produce elevation data referenced to the North American Vertical Datum of 1988. Offsets presented in this report can be used in the evaluation of water-surface elevations in a common datum for Lake Champlain and the Richelieu River. In addition, the water-level data referenced to the common datum (as determined from the offsets) may be used to calibrate flow models and support future modeling studies developed for Lake Champlain and the Richelieu River. 


\section{Introduction}

During spring and early summer 2011, Lake Champlain and the Richelieu River (fig. 1) were affected by historic flooding because of a warm, saturated, late-spring snowpack coupled with spring rainfall across the St. Lawrence Basin (not shown). As a result of melting snow (from the third highest snowfall year on record [National Weather Service, 2012]) and rainfall, historically high flood levels were observed in Lake Champlain and the Richelieu River beginning in late April and continuing through May 2011. Shoreline erosion and variable lake elevations during flooding were exacerbated by winddriven waves associated with local fetch and lake-wide seiche effects (Bjerklie and others, 2014). Lake-wide seiche effects (standing oscillating wave with a long wavelength) were previously reported on the lake by Shanley and Denner (1999) and are created by wind and atmospheric pressure changes.

In May 2011, a new water-surface elevation-record was set for Lake Champlain. The maximum recorded stage at U.S. Geological Survey (USGS) lake gage 04295000, Richelieu River (Lake Champlain) at Rouses Point, New York (fig. 1; U.S. Geological Survey, 2015b), was 103.20 feet (ft) above the National Geodetic Vertical Datum of 1929 (NGVD 29) on May 6, 2011. The maximum stage at USGS lake gage 04294500, Lake Champlain at Burlington, Vermont (fig. 1; U.S. Geological Survey, 2015a), was $103.27 \mathrm{ft}$ (NGVD 29) on May 6, 2011. The maximum recorded stage at the USGS lake gage 04279085, Lake Champlain North of Whitehall, N.Y. (fig. 1; U.S. Geological Survey, 2015c), was $103.57 \mathrm{ft}$ (NGVD 29) on May 9, 2011; the stage was affected by wind and seiche. The water-surface elevations for the Richelieu River in Canada are referenced to different vertical datums than those in Lake Champlain in the United States, which causes difficulty in assessing real-time flood watersurface elevations and comparing of flood peaks in the Lake Champlain Basin in the United States and Canada.

At USGS lake gage 04295000, Richelieu River (Lake Champlain) at Rouses Point, N.Y. (fig. 1), major flood stage, as designated by the National Weather Service, is $101.5 \mathrm{ft}$ (NGVD 29), moderate flood stage is $101.0 \mathrm{ft}$ (NGVD 29), and minor flood stage is $100.0 \mathrm{ft}$. (NGVD 29) (National Weather Service, 2015). As a result of the rainfall and runoff events of April and May 2011, Lake Champlain was above flood stage for 67 consecutive days, from April 13 to June 19, 2011, and reached its recorded maximum stage on May 6, 2011. Lake Champlain was above the National Weather Service-designated major flood stage for May 2011 (Bjerklie and others, 2014). During flooding, shoreline erosion, flood inundation, and damage were exacerbated by wind-driven waves associated with local fetch and lake-wide seiche effects resulting in wave heights in excess of $3 \mathrm{ft}$ (Lake Champlain Basin Program, 2013). As a result of the May 2011 flooding, Vermont declared a state of emergency, and a Presidential disaster declaration (declaration number 1995-DR; Federal Emergency Management Agency, 2011) was made on June 15, 2011.
The flood event of April and May 2011 resulted in governmental requests to the International Joint Commission (IJC) to investigate options for flood mitigation. On March 19, 2012, the Governments of Canada and the United States asked the IJC to draft a plan of study to examine the causes and effects of the spring 2011 flooding on Lake Champlain and the Richelieu River and develop potential mitigation measures. The IJC established the International Lake ChamplainRichelieu River Technical Working Group to develop the requested plan of study (International Joint Commission, 2013); specific challenges noted by the work group included a harmonization of vertical datums within the drainage basin.

Discrepancies in the elevation datums for lake gage and streamgage data were observed at the border of Canada and the United States for the Canadian Geodetic Vertical Datum of 1928 (CGVD 28), North American Vertical Datum of 1988 (NAVD 88), and NGVD 29, requiring geospatial datum harmonization for consistency and continuity. Published water levels indicate that the Missisquoi Bay water surface, as referenced to the CGVD 28, would be lower than at Rouses Point in the United States, as referenced to the NGVD 29, by about $0.354 \mathrm{ft}$ (NGVD $29-$ CGVD $28=0.354 \mathrm{ft}$ ) and higher than at Rouses Point, as referenced to the NAVD 88, by about $0.098 \mathrm{ft}$ (CGVD $28-\mathrm{NAVD} 88=0.098 \mathrm{ft}$ ) (International Joint Commission, 2013). Harmonization of the vertical datum discrepancy is needed for flood assessment and future efforts to develop accurate digital elevation models and hydraulic models that describe the movement of water through the Lake Champlain Basin in the United States and Canada. Therefore, obtaining accurate elevation data in a uniform vertical datum is critical to understanding and managing water-surface elevations in the Lake Champlain Basin. In April 2015, the USGS and Environment Canada (EC) began a joint field effort with the goal of obtaining precise elevations representing a common vertical datum for select reference marks used to determine water-surface elevations throughout Lake Champlain and the Richelieu River.

Elevations as defined by ellipsoids, geoids, and topography are all attempts to model the shape of the Earth by using spatial coordinate systems. An ellipsoid is spherical with a polar radius that is shorter in length than the equatorial radius. Its center coincides with the predicted center of the Earth and is best-fitted to the overall shape of the Earth. The geoid is a model that represents the mean global sea level of the Earth under the influence of gravitation and rotation alone. The vertical distance between the geoid and ellipsoid is called the geoid height, and it can be either positive or negative. Topographic heights are usually created by using satellite, light detection and ranging, or aerial photography with elevations computed relative to average sea level. The difference between the topographic elevation and ellipsoid is called the ellipsoid height. The difference between the topographic elevation and geoid is called the orthometric height (GISTutor, 2015).

In 2013, a new vertical datum for Canada was released by Natural Resources Canada (NRCan) to replace the CGVD 28 that was defined by mean sea level at tide gages on the 

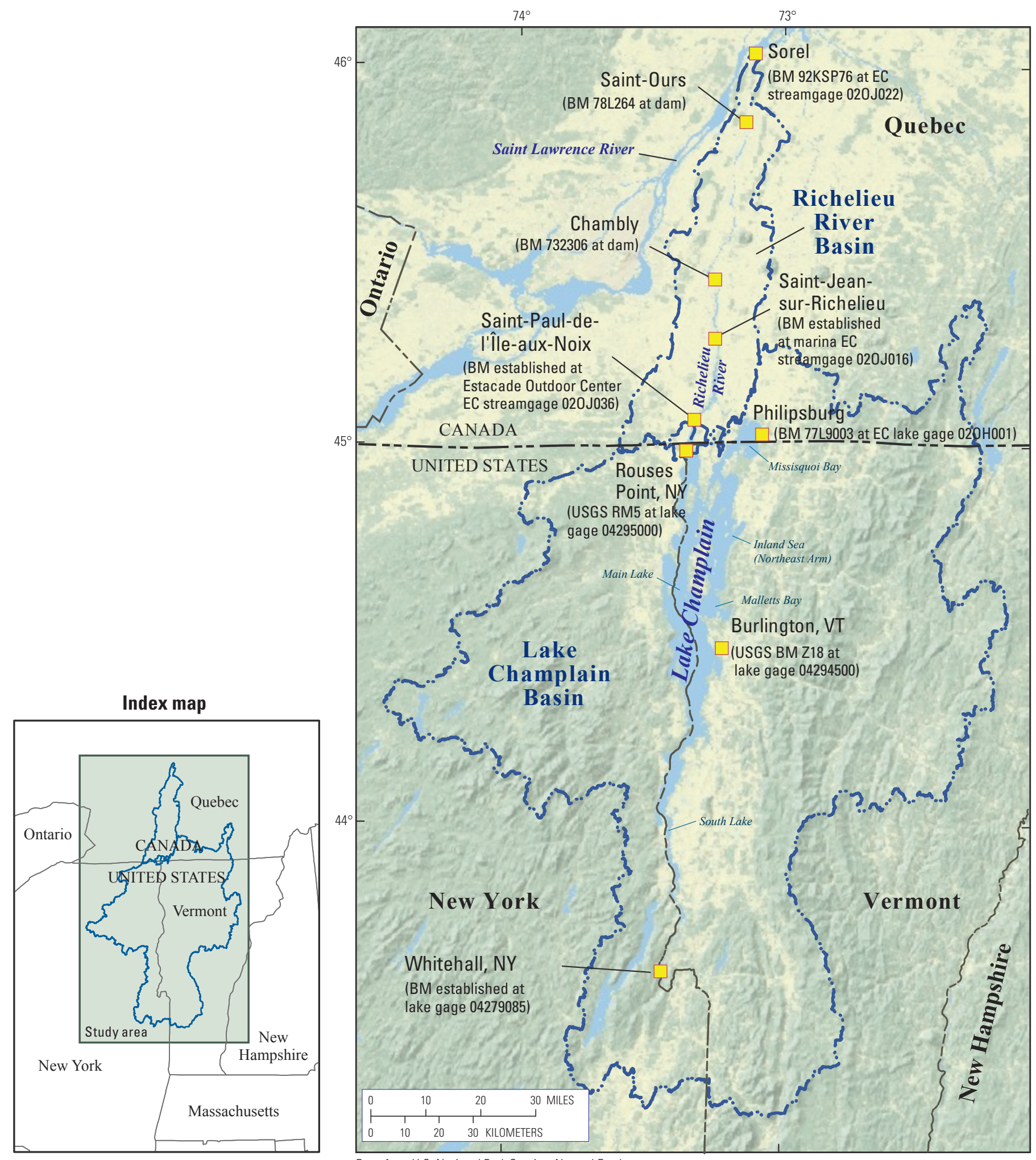

Base from U.S. National Park Service, Natural Earth

physical map, 500-meter resolution, services.arcgisonline.com, 2015

Vermont State Plane projection

North American Datum of 1983

EXPLANATION

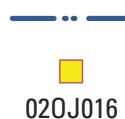

Basin boundary

Global Navigation Satellite System observation benchmark (BM) and number, or reference mark (RM) and number-Environment Canada (EC) numbers also shown

Figure 1. Lake Champlain Basin including Global Navigation Satellite System lake gages, streamgages, and dam benchmarks surveyed by the U.S. Geological Survey (USGS). 
Canadian east and west coasts. The new Canadian Geodetic Vertical Datum of 2013 (CGVD2013) is a geoid-based datum (Natural Resources Canada, 2013). This surface, agreed to by the National Geodetic Survey (NGS) of the United States and Canadian Geodetic Survey (CGS) in 2012, represents the mean potential of the mean sea level at a series of tide gages across Canada and the United States. The CGVD2013 is evolved from the Canadian Gravimetric Geoid model of 2013 (CGG 2013; Natural Resources Canada, 2013).

In 1993, the NAVD 88 was federally registered as the official vertical datum of the National Spatial Reference System for the conterminous United States and Alaska and remains the official vertical datum to date [2015]; however, it should be noted that, with the exception of the recently (April 2015) established lake gage 04294620 (Lake Champlain near Grande Isle, Vt.), the U.S. lake gages on Lake Champlain have remained referenced to the older NGVD 29. The NGS plans to replace NAVD 88 with a gravity-based vertical datum in 2022 under the Gravity for the Redefinition of the American Vertical Datum proposal in accordance to its 10-year plan (National Geodetic Survey, 2014). The NAVD 88 extends into Canada as do American geoid models (currently GEOID12A), but the NAVD 88 was never adopted in Canada.

\section{Purpose and Scope}

The purpose of this report is to describe the data collection methods and the adjustment to water-level data for the Lake Champlain Basin such that all the water-level gages in the basin can be referenced to a single datum. This report contains precise elevations for the nine Lake Champlain Basin benchmarks (fig. 1); seven of the gages at these benchmarks are part of the level circuit for active gages that provide realtime, continuous water-level data for Lake Champlain and continuous water-level and discharge data for the Richelieu River. These gages are operated by the USGS in the United States and by EC in Canada. Water-level gages throughout the Lake Champlain Basin (fig. 1) are used in the regulation of water levels; however, different vertical datums are used in the United States and Canada to determine water levels at these gages (table 1). In the United States, Lake Champlain water-surface-elevation data are referenced to the NGVD 29 and NAVD 88, whereas in Canada, the Richelieu River streamgages are referenced to the CGVD 28.

From April 14 to 16, 2015, personnel from the USGS, EC, the NGS, and the CGS took part in a joint effort to create a vertical datum transformation such that all water-surfaceelevation data in the Lake Champlain Basin study area (comprising Lake Champlain, the Richelieu River, and their flood plains) could be converted to either the NAVD 88, CGVD 28, or CGVD2013. Global Navigation Satellite System (GNSS) surveys were completed at seven gages (four lake gages and three streamgages) and two dam locations to collect simultaneous satellite data that were processed to obtain elevations with centimeter-precision-level ellipsoid heights referenced to the latest American realization of the North American Datum of 1983 (NAD 83), currently NAD 83(2011) epoch 2010.00 (this geometric reference frame is equivalent to the Canadian NAD 83 [Canadian Spatial Reference System (CSRS)] epoch 2010.0). The NAVD 88 or CGVD2013 orthometric heights were determined by applying either GEOID12A or CGG 2013 geoid heights.

Table 1. Lake Champlain and Richelieu River water-level gages and dam benchmarks used in the Global Navigation Satellite System Surveys.

[ID, identification; EC, Environment Canada; CGVD 28, Canadian Geodetic Vertical Datum of 1928; USGS, U.S. Geological Survey; NGVD 29, National Geodetic Vertical Datum of 1929; NY, New York; VT, Vermont; --, not a lake gage or streamgage]

\begin{tabular}{lclcccc}
\hline $\begin{array}{c}\text { Benchmark } \\
\text { ID }\end{array}$ & $\begin{array}{c}\text { Station } \\
\text { name }\end{array}$ & \multicolumn{1}{c}{ Site name } & $\begin{array}{c}\text { Agen- } \\
\text { cy }\end{array}$ & $\begin{array}{c}\text { Vertical } \\
\text { datum }\end{array}$ & $\begin{array}{c}\text { Gage } \\
\text { start date }\end{array}$ & $\begin{array}{c}\text { Gage } \\
\text { end date }\end{array}$ \\
\hline 92KSP76 & 02OJ022 & Saint Lawrence River at Sorel, Quebec, Canada & EC & CGVD 28 & 1912 & 2011 \\
78L264 & -- & Richelieu River at Saint-Ours dam at Saint-Ours, Quebec, Canada & EC & CGVD 28 & -- & -- \\
732306 & -- & Richelieu River at Fryers Dam at Chambly, Quebec, Canada & EC & CGVD 28 & -- & -- \\
Established & 02OJ016 & Richelieu River at Saint-Jean-sur-Richelieu, Quebec, Canada & EC & CGVD 28 & 1972 & Present $^{1}$ \\
Established & 02OJ036 & Richelieu River at Saint-Paul-de-I'Île-aux-Noix, Quebec, Canada & EC & CGVD 28 & 2011 & Present $^{1}$ \\
77L9003 & $02 \mathrm{OH} 001$ & Lake Champlain at Philipsburg, Quebec, Canada & USGS & NGVD 29 & 1964 & Present $^{1}$ \\
USGS RM5 & 04295000 & Richelieu River (Lake Champlain) at Rouses Point, NY, United States & USGS & NGVD 29 & 1871 & Present $^{1}$ \\
Established & 04294500 & Lake Champlain at Burlington, VT, United States & USGS & NGVD 29 & 1907 & Present $^{1}$ \\
Established & 04279085 & Lake Champlain north of Whitehall, NY, United States & USGS & NGVD 29 & 1999 & Present $^{1}$ \\
\hline
\end{tabular}

${ }^{1}$ Gage is operational as of publication date. 


\section{Study Area Description}

Lake Champlain is a freshwater lake with about 435 square miles $\left(\mathrm{mi}^{2}\right)$ of surface area (Lake Champlain Basin Program, 2015) primarily within the borders of the United States but partially situated in the Canadian Province of Quebec. It is the largest freshwater lake in the United States outside of the five Great Lakes (Stickney and others, 2001). Water transiting through Lake Champlain flows north from Whitehall, N.Y., to the American and Canadian border at its outlet at the Richelieu River in Quebec. The Richelieu River flows into the St. Lawrence River at Sorel, Quebec, Canada, which flows into the Atlantic Ocean at the Gulf of St. Lawrence. The Richelieu River extends from Rouses Point, N.Y., downstream to Sorel, Quebec, Canada. Lake Champlain is about 120 miles (mi) in length, extending from Whitehall, N.Y., in the south to the Richelieu River in Quebec, Canada (Lake Champlain Basin Program, 2015). Visually, there are three distinct regions in Lake Champlain (Bjerklie and others, 2014); the southern region is narrow and riverlike, the central region is wide with some small islands (not shown), and the northern region is the widest with several large islands (not shown). Tributaries to Lake Champlain are primarily highgradient streams, which peak within 24 hours in response to precipitation or snowmelt. The dominant hydrologic event during the year is spring snowmelt, when typically nearly one-half of the annual streamflow happens in a 6 to 8 week period (Shanley and Denner, 1999). The response of the Lake Champlain outflow to inflow is not instantaneous, and the lake plays an important role in regulating flow to the Richelieu River. Because of the storage capacity of the lake, lake-elevation peak lags the peak inflow by several days. The Richelieu River and Lake Champlain Basins are dominated by strong spring flooding and more moderate flows throughout the rest of the year. Richelieu River discharge is effectively controlled by the water level in Lake Champlain with about 95 percent of the Richelieu River's outlet flow into the St. Lawrence River originating in Lake Champlain (Riboust and Brissette, 2015).

The drainage basin area for Lake Champlain is 8,234 $\mathrm{mi}^{2}$ with 56 percent of the basin in Vermont, United States; 37 percent in New York, Unites States; and 7 percent in the Province of Quebec, Canada. The population distribution in the drainage basin consists of 68 percent in Vermont, Unites States; 27 percent in New York, Unites States; and 5 percent in Quebec, Canada (Lake Champlain Basin Program, 2015). Lake Champlain is surrounded by mountains: the Green Mountains to the east in Vermont, the Adirondacks to the west in New York, and the Taconic Mountains to the south in New York and Vermont. Mean precipitation in the Lake Champlain drainage basin varies between 30 and 50 inches per year depending on location within the drainage basin (Howland and others, 2006). The mean air temperature within the Lake Champlain Basin is 7 degrees Celsius (Shanley and Denner, 1999).
Lake Champlain was formed about 11,000 years ago as the last glacial period ended and left behind a large body of freshwater that included the Great Lakes, Lake Champlain, and much of the St. Lawrence River valley (Lake Champlain Research Consortium, 2004). Lake Champlain has about $587 \mathrm{mi}$ of shoreline and is $12 \mathrm{mi}$ at its widest point with an average depth of $64 \mathrm{ft}$, although the deepest point is between Charlotte, Vt., and Essex, N.Y., with a depth of $400 \mathrm{ft}$ (Lake Champlain Land Trust, 2015). Average annual water level is $95.5 \mathrm{ft}$ (NGVD 29) with an average annual variation between high and low average water levels of about $6 \mathrm{ft}$ and a maximum range of $9.4 \mathrm{ft}$ since the $1870 \mathrm{~s}$ when daily records began (Lake Champlain Basin Program, 2015). After floods in the 1930s, a dam was built in 1939 at Fryers Island (not shown) to regulate the Richelieu River flow (Riboust and Brissette, 2015); however, levees around the dam and dredging of the shoals at Saint-Jean-sur-Richelieu (fig. 1) were never done (International Joint Commission, 2013). The dam at Fryers Island was never put into service, and the Richelieu River remains unregulated (Riboust and Brissette, 2015).

Lake Champlain is in the physiographic province of the Champlain Lowlands (not shown). Although visually there are three distinct regions in the lake (Bjerklie and others, 2014), based on different physical and chemical characteristics and water quality, the lake is divided into five distinct areas (Lake Champlain Basin Program, 2015). The lake areas include the following: the South Lake, the Main Lake (or Broad Lake), Malletts Bay, the Inland Sea (or Northeast Arm), and Missisquoi Bay. Water retention time is about 3 years in the Main Lake and less than 2 months in the South Lake (Lake Champlain Basin Program, 2015). With a population of 42,284, Burlington, Vt., is the largest city on the lake (in 2013, U.S. Census Bureau, 2015a). The second and third most populated cities are Plattsburgh, N.Y., and Colchester, Vt., with populations of 19,898 (in 2013, U.S. Census Bureau, 2015b) and 17,299 (in 2013, U.S. Census Bureau, 2015c), respectively.

\section{Methods}

In this study, the USGS, in collaboration with EC, the NGS, and the CGS, deployed dual-frequency, surveygrade GNSS receivers to complete simultaneous static surveys (Canadian Geodetic Survey, 2003, 2013; Rydlund and Densmore, 2012) at seven gage benchmarks on Lake Champlain and the Richelieu River and two benchmarks associated with two dams on the Richelieu River in Canada. Because of the different vertical datums in the United States and Canada, a height transformation was required to establish a common vertical datum for a study of flood water-surface elevations of the Lake Champlain Basin, which includes Lake Champlain and the Richelieu River. This transformation was required as a response to the Lake Champlain-Richelieu River Technical Working Group data needs for hydraulic modeling 
and flood forecasting of Lake Champlain and the Richelieu River. The GNSS surveys were completed at survey control disks (benchmarks) at lake gages, streamgages, and two dam locations within the Champlain-Richelieu drainage basin. The survey measurements were used to create a vertical datum transformation such that all of the data available in the study area can be converted to either the NAVD 88 or CGVD2013.

The approach to datum harmonization for Lake Champlain involved measuring the ellipsoid height to centimeter level with GNSS static observations at four lake gages located in Whitehall, N.Y., United States; Burlington, Vt., United States; Rouses Point, N.Y., United States; and Philipsburg, Quebec, Canada; and three streamgages in Saint-Paul de l'Île aux Noix, Quebec, Canada; Saint-Jean-sur-Richelieu, Quebec, Canada; and Sorel, Quebec, Canada; and two dams, Fryers Dam at Chambly, Quebec, Canada; and Saint-Ours dam at Saint-Ours, Quebec, Canada (fig. 1). Orthometric heights, or elevations, were calculated from the ellipsoid heights by using current geoid models (GEOID12A and CCG 2013).

The GNSS observations at benchmarks and differential levels were used to obtain precise elevations representing a common vertical datum for the targeted lake gage or streamgage reference marks. For this report, a "benchmark" is defined as the mark where the geodetic elevation was determined from the GNSS survey, a "reference mark" is defined as the mark that represents a perpetuated elevation used to determine water level at the lake gage or streamgage, and "survey control" refers to a mark with published vertical and horizontal datum. Reference marks were updated to the common vertical datum by using differential levels to perpetuate the GNSS-surveyed elevations from the benchmarks. In some cases, the benchmark was also the reference mark.

The GNSS observations were completed by using survey reference marks that represented the origin of a differential leveling circuit at each of the nine locations described in this section. Benchmarks were established at two Lake Champlain lake gages and two Richelieu River streamgages because of their lack of suitability for GNSS satellite observations, distance of established monuments from survey control, or absence of survey control. Benchmarks were established for GNSS observations on April 14, 2015, at the following lake gages and streamgages: USGS lake gage 04279085, Lake Champlain north of Whitehall, N.Y., United States; USGS lake gage 04294500, Lake Champlain at Burlington, Vt., United States; EC streamgage 02OJ016 Saint-Jean-surRichelieu, Quebec, Canada; and EC streamgage 02OJ036 Saint-Paul-de-l'Île-aux-Noix, Quebec, Canada. Elevations from all established benchmarks or available reference marks were perpetuated to the established leveling network (Kenney, 2010; Canadian Geodetic Survey, 2013) of the lake gage or streamgage by way of differential leveling. The remaining sites had pre-established benchmarks that were acceptable for the GNSS surveys and the differential leveling surveys to tie to the reference marks in the established lake gage or streamgage level network.
The GNSS observations at lake gages and streamgages consisted of simultaneous 12-hour observations on April 15, 2015, followed by simultaneous 6-hour observations on April 16, 2015, for redundancy. The GNSS observations at Fryers Dam at Chambly (7 hours) and Saint-Ours dam at Saint-Ours (6 hours) consisted of simultaneous 5-hour observations on April 14, 2015. There was no redundant observation the following day (April 15, 2015) at Fryers Dam at Chambly and Saint-Ours dam.

Although 4-hour observations are generally sufficient for geodetic control nationwide, along with recommended redundant 4-hour observations to increase confidence, the observation sessions for this study consisted of 12-hour observations with redundant 6-hour observations for additional precision. Observations longer than 4 hours yield a small improvement in precision (Eckl and others, 2001). It is commonly accepted that longer observations will yield more precise results of the NAD 83 ellipsoid height, which translates to a more precise NAVD 88 orthometric height estimate.

Although the GNSS antennas were all microcentered, all antennas were oriented to north for added precision. The orientation plays a part in the precision of the absolute antenna phase center models used since they include not only the elevation but also the azimuth of the satellite. Continuously Operating Reference Station network antennas are also oriented to north.

The GNSS observations for the lake gages and streamgages, along with the locations at the dams, were initially postprocessed in the United States by using the NGS Online Positioning User Service (OPUS; National Geodetic Survey, 2015b). The OPUS solutions will be shared to the OPUS database. The GNSS observations were also processed by the CGS using NRCan CSRS-Precise Point Positioning (PPP).

\section{Field Data Collection}

The USGS field crews deployed seven static GNSS units in the United States and Canada for GNSS data collection from April 15 (Julian day 105) through April 16, 2015 (Julian day 106) at specified lake gages and streamgages (table 1 , fig. 1). Field crews deployed static GNSS units in Canada for satellite data collection on April 14, 2015 (Julian day 104), at two dam locations (table 1, fig. 1). Field data collection procedures used during the GNSS surveys followed guidelines established for static network surveys as described in NRCan (Canadian Geodetic Survey, 2013) and USGS guidelines (Rydlund and Densmore, 2012). A clear view of the sky was available during GNSS observations at all locations from April 14 through April 16, 2015. Four benchmarks were established, and differential levels were used to measure elevation differences between GNSS observation benchmarks and gage reference marks. Log files from the GNSS surveys are available in appendixes 1 and 2 and contain details such as antenna height during data collection and descriptive location 
of the benchmarks. Instantaneous water-surface elevations were obtained at each site by using readings from active gages as disseminated from the National Water Information System (U.S. Geological Survey, 2015d, e) and EC Wateroffice (Environment Canada, 2015) or measured directly from the established reference mark by using differential levels.

Potential limitations to the GNSS survey were poor satellite data quality, errors in leveling between GNSS survey benchmarks and reference marks, and GNSS multipath errors. Multipath errors are a result of reflected signals to the GNSS receiver and may be due to proximity of the GNSS units to the water surface combined with surrounding tree cover. In reviewing the data, satellite and data quality were determined to be adequate.

\section{Data Processing}

EC (in collaboration with the CGS) and the USGS (in collaboration with the NGS) processed GNSS observations independently by using different methods. The CGS staff processed the static GNSS survey data by using CSRS-PPP (Kouba and Héroux, 2001) to obtain ellipsoid heights. The CGG 2013 was applied to postprocessed data from CSRSPPP to obtain orthometric heights in the CGVD2013 (Huang and Véronneau, 2013; Véronneau and others, 2014a, b). The National Oceanic and Atmospheric Administration NGS personnel processed the GNSS static survey data through the NGS OPUS Projects software (National Geodetic Survey, 2015b) to establish survey-grade geographic and grid coordinates, along with ellipsoid heights (National
Geodetic Survey, 2012b). The NAVD 88 orthometric heights were calculated by using GEOID12A (National Geodetic Survey, 2012a) for each benchmark. A network adjustment of all benchmarks relative to the Continuously Operating Reference Station network (National Geodetic Survey, 2015a) was completed by using OPUS Projects (National Geodetic Survey, 2014c).

\section{Gage Datum Offsets}

The Canadian streamgage and American lake gage vertical datums used to determine water-surface elevations are presented in table 1. The GNSS-derived elevation data were used to develop offsets for conversion of published watersurface elevations to NAVD 88 elevations, either through GNSS observations at gage reference marks or differential leveling between established monuments with GNSS observations and gage reference marks. Offset elevation data presented are based on the conversion of datums to the NAVD 88 from published datums in either the NGVD 29 or CGVD 28.

\section{GNSS Survey Harmonization Results}

The measured ellipsoid and orthometric heights of all survey points computed with the NGS OPUS Projects software (National Geodetic Survey, 2015b) are presented in table 2. Results of the OPUS static data processing are in appendix 2. Leveling information between GNSS-surveyed

Table 2. Global Navigation Satellite System benchmark survey results from Online Positioning User Service Projects network adjustment.

[ID, identification; OPUS, Online Positioning User Service; ft, feet; WGS 84, World Geodetic System 1984; NAVD 88, North American Vertical Datum of 1988; NAD 83, North American Datum of 1983; NY, New York; VT, Vermont; --, not a lake gage or streamgage]

\begin{tabular}{|c|c|c|c|c|c|}
\hline $\begin{array}{c}\text { Benchmark } \\
\text { ID }\end{array}$ & $\begin{array}{l}\text { Station } \\
\text { name }\end{array}$ & Site name & $\begin{array}{l}\text { Ellipsoid } \\
\text { height } \\
\text { (ft) }\end{array}$ & $\begin{array}{c}\text { Geoid } \\
\text { height, } N_{12} \\
\text { (ft) }\end{array}$ & $\begin{array}{l}\text { OPUS } \\
\text { orthometric } \\
\text { height } \\
\text { (ft) }\end{array}$ \\
\hline & & & 'NAD 83 & GE0ID12A & NAVD 88 \\
\hline 92KSP76 & 02OJ022 & Saint Lawrence River at Sorel, Quebec, Canada & -75.889 & -102.812 & 26.923 \\
\hline 78L264 & -- & Richelieu River at Saint-Ours dam at Saint-Ours, Quebec, Canada & -56.486 & -102.073 & 45.587 \\
\hline 732306 & -- & Richelieu River at Fryers Dam at Chambly, Quebec, Canada & -30.463 & -99.636 & 69.173 \\
\hline Established & $02 \mathrm{OJ} 016$ & Richelieu River at Saint-Jean-sur-Richelieu, Quebec, Canada & 0.758 & -98.747 & 99.505 \\
\hline Established & $02 \mathrm{OJ} 036$ & Richelieu River at Saint-Paul-de-I'Île-aux-Noix, Quebec, Canada & 11.499 & -97.316 & 108.816 \\
\hline 77L9003 & $02 \mathrm{OH} 001$ & Lake Champlain at Philipsburg, Quebec, Canada & 5.755 & -96.667 & 102.421 \\
\hline USGS RM5 & 04295000 & Richelieu River (Lake Champlain) at Rouses Point, NY, United States & 5.558 & -96.572 & 102.129 \\
\hline Established & 04294500 & Lake Champlain at Burlington, VT, United States & 7.169 & -95.364 & 102.533 \\
\hline Established & 04279085 & Lake Champlain north of Whitehall, NY, United States & 6.066 & -96.745 & 102.812 \\
\hline
\end{tabular}

${ }^{1}$ NAD 83(2011) epoch 2010.00. 
points and gage reference marks is in appendix 3 . Results of data processing using OPUS Projects are presented in appendix 4 of this report for converting water-surface elevation-data at a gage to a single, uniform vertical datum (Huang and Véronneau, 2013; Véronneau and others, 2014a, b).

Offsets between published gage water-surface elevations and NAVD 88 elevations were developed by using GNSSderived elevations and differential leveling information (appendix 4). Daily mean, maximum, and minimum water levels (NAVD 88) for the data collection period (Julian days 104-106) at USGS lake gages in Lake Champlain were calculated (fig. 2). The average water-surface elevation at Whitehall, N.Y., in the southern part of Lake Champlain was higher than the average water-surface elevation in the northern part of the lake (Rouses Point, N.Y., and Burlington, Vt.) (fig. 2). Wind and seiche were contributing factors to the high water-surface elevation in the southern part of the lake.

Lake gages for Lake Champlain are in Philipsburg, Quebec, Canada (EC streamgage 02OH001); Rouses Point, N.Y. (USGS lake gage 04295000); Burlington, Vt. (USGS lake gage 04294500); and Whitehall, N.Y. (USGS lake gage 04279085). Streamgages in the Richelieu River in Quebec, Canada, are at Sorel (EC streamgage 02OJ022), Saint-Jean-sur-Richelieu (EC streamgage 02OJ016), and Saint-Paul-de-l'Île-aux-Noix (EC streamgage 02OJ036) (fig. 1). Elevation offset information between GNSS-derived benchmarks and gage reference marks is in table 3 and appendix 4.

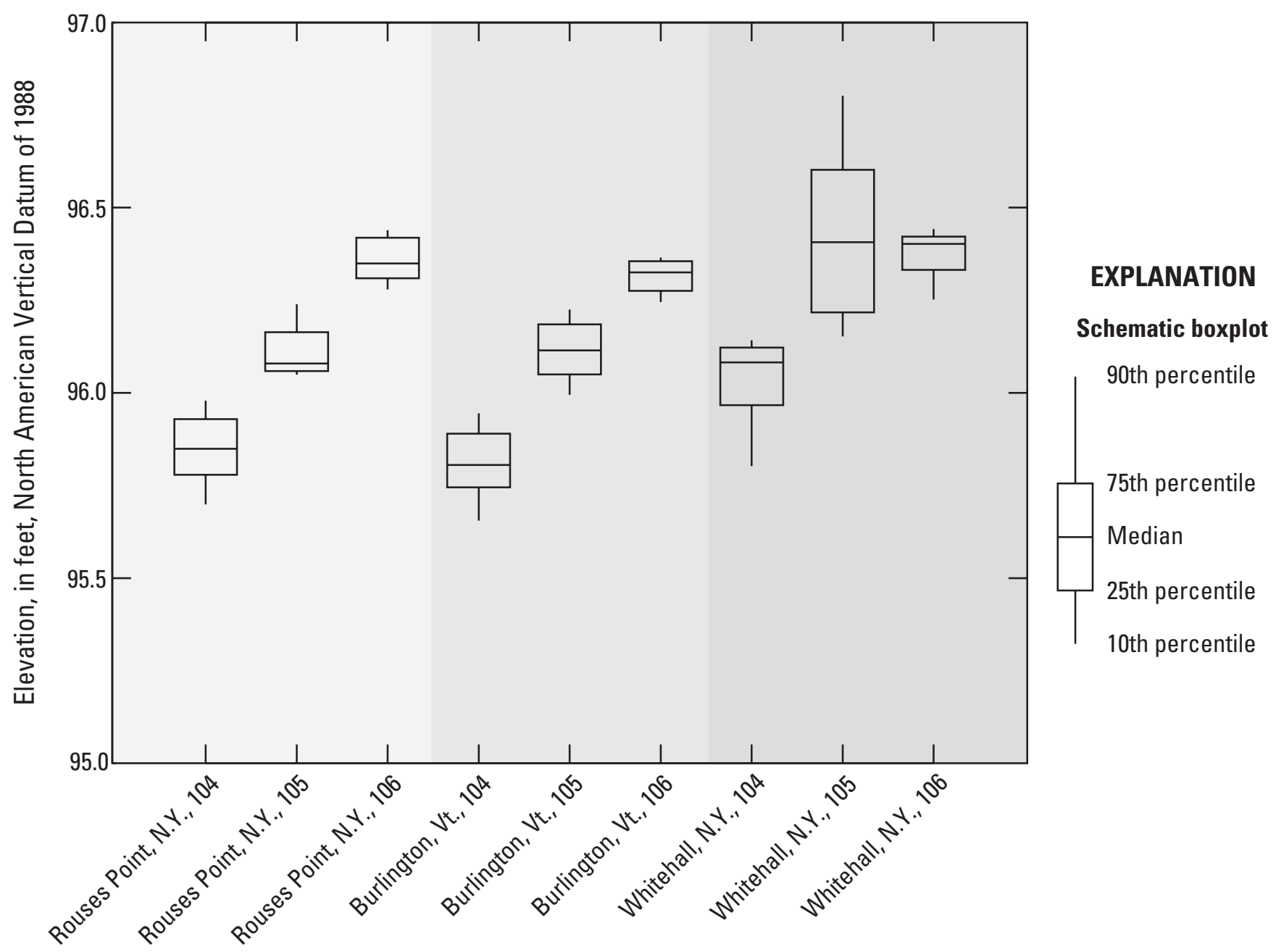

City, State, and Julian day 104-106 (April 14-16, 2015)

Figure 2. Instantaneous water-surface elevations referenced to the North American Vertical Datum of 1988, from the Global Navigation Satellite System surveys, for the data collection period (Julian days 104-106) at U.S. Geological Survey lake gages in Lake Champlain. 
Table 3. Offsets for conversion of published water-surface elevations to the North American Vertical Datum of 1988 for lake gages in Lake Champlain and streamgages in the Richelieu River.

[ft, feet; NAVD 88, North American Vertical Datum of 1988; EC, Environment Canada; CGVD 28, Canadian Geodetic Vertical Datum of 1928; USGS, U.S. Geological Survey; NGVD 29, National Geodetic Vertical Datum of 1929; NY, New York; VT, Vermont]

\begin{tabular}{|c|c|c|c|c|}
\hline $\begin{array}{l}\text { Station } \\
\text { name }\end{array}$ & Site name & Agency & $\begin{array}{l}\text { Datum of published } \\
\text { elevation data }\end{array}$ & $\begin{array}{l}\text { Offset (ft) to convert } \\
\text { published elevation } \\
\text { data to NAVD 88' }\end{array}$ \\
\hline 02OJ022 & Saint Lawrence River at Sorel, Quebec, Canada & EC & CGVD 28 & +0.115 \\
\hline $02 \mathrm{OJ} 016$ & Richelieu River at Saint-Jean-sur-Richelieu, Quebec, Canada & $\mathrm{EC}$ & CGVD 28 & -0.061 \\
\hline $02 \mathrm{OJ} 036$ & Richelieu River at Saint-Paul-de-I'Île-aux-Noix, Quebec, Canada & $\mathrm{EC}$ & CGVD 28 & -0.206 \\
\hline 02OH001 & Lake Champlain at Philipsburg, Quebec, Canada & $\mathrm{EC}$ & CGVD 28 & -0.213 \\
\hline 04294500 & Lake Champlain at Burlington, VT, United States & USGS & NGVD 29 & -0.523 \\
\hline 04279085 & Lake Champlain north of Whitehall, NY, United States & USGS & NGVD 29 & -0.268 \\
\hline
\end{tabular}

${ }^{1}$ The number of decimal places shown corresponds to the number of decimal places published for the site.

\section{Summary}

During spring and early summer 2011, the Lake Champlain region experienced historic flooding because of a warm, saturated late spring snowpack coupled with spring rainfall across the St. Lawrence Basin. As a result of melting snow (from the third highest snowfall year on record) and rainfall, historically high flood levels were observed in Lake Champlain from late April through May 2011. Flood stage was exceeded for a total of 67 days from April 13 to June 19, 2011. Shoreline erosion and variable lake elevations during flooding were exacerbated by wind-driven waves associated with local fetch and lake-wide seiche effects. May 2011 peak water-surface elevations for Lake Champlain ranged from 103.20 feet above the National Geodetic Vertical Datum of 1929 at the northern end of Lake Champlain, at its outlet into the Richelieu River at Rouses Point, New York, to 103.57 feet (National Geodetic Vertical Datum of 1929) at the southern end of the lake in Whitehall, N.Y. An assessment of flood water-surface elevations in the basin was difficult because the water-surface elevations for the Richelieu River in Canada are referenced to a different vertical datum than are those in the United States, thus making an assessment of real-time flood water-surface elevations and comparison of flood peaks in the Lake Champlain Basin difficult.

As a result of the flood event of April and May 2011, the Governments of Canada and the United States asked the International Joint Commission to draft a plan of study to examine the causes and the effects of the spring 2011 flooding on Lake Champlain and the Richelieu River and develop potential mitigation measures. Specific challenges noted by the work group included a harmonization of vertical datums within the drainage basin for future efforts to model the flow of water through the Lake Champlain Basin.

In April 2015, the U.S. Geological Survey and Environment Canada began a joint field effort with the goal of obtaining precise elevations representing a common vertical datum for select reference marks used to determine water-surface elevations throughout Lake Champlain and the Richelieu River. In order to harmonize the difference between datums used in the United States and Canada, Global Navigation Satellite System surveys were completed at nine locations to collect simultaneous satellite data that were processed to produce elevations for two reference marks associated with dams and seven reference marks associated with active water-surface-elevation gages (lake gages in Lake Champlain and streamgages in the Richelieu River) throughout the Lake Champlain Basin. The Global Navigation Satellite System surveys were completed April 14-16, 2015, at locations ranging from southern Lake Champlain near Whitehall, New York, to the northern end of the Richelieu River in Sorel, Quebec (at its confluence with the St. Lawrence River in Canada).

Precise elevations were obtained in a uniform vertical datum (the North American Vertical Datum of 1988) at benchmarks used in the Global Navigation Satellite System surveys for datum harmonization of water levels at seven gage sites and two dams in Lake Champlain and the Richelieu River. Environment Canada, in collaboration with the Canadian Geodetic Survey, processed raw static Global Navigation Satellite System survey data by using Natural Resources Canada's Canadian Spatial Reference SystemPrecise Point Positioning. The U.S. Geological Survey, in collaboration with the National Geodetic Survey of the National Oceanic and Atmospheric Administration, processed 
static data independently by using Online Positioning User Service Projects. Results from the network adjustment of the static Global Navigation Satellite System survey data processed using Online Positioning User Service Projects were selected for calculating offsets that convert published gage water levels to North American Vertical Datum of 1988 elevations.

Lake-gage water-surface elevations determined during the 3-day survey were converted to elevations referenced to the North American Vertical Datum of 1988 by using calculated offsets, and elevations demonstrated good hydrologic agreement among gages. Water-level offsets, determined as a result of the Global Navigation Satellite System surveys in the Lake Champlain Basin, can be used in the evaluation of flow from Lake Champlain in the United States through the Richelieu River in Canada. Water-level corrections will provide the information needed to calibrate flow models developed by Environment Canada for the Richelieu River and Lake Champlain; furthermore, improved accuracy of reference mark and water-surface elevations will enhance a digital elevation model being developed by Environment Canada and will benefit other modeling studies designed to assess the effects of flooding in the Lake Champlain Basin.

\section{References Cited}

Bjerklie, D.M., Trombley, T.J., and Olson, S.A., 2014, Assessment of the spatial extent and height of flooding in Lake Champlain during May 2011, using satellite remote sensing and ground-based information: U.S. Geological Survey Scientific Investigations Report 2014-5163, 18 p. [Also available at http://dx.doi.org/10.3133/sir20145163.]

Canadian Geodetic Survey, 2003, Standard operational procedure-Static GPS surveys: Ottawa, Canada, Canadian Geodetic Survey, Natural Resources document GGN-04, v. $1.0,9 \mathrm{p}$.

Canadian Geodetic Survey, 2013, Standard operational procedure-Field operations: Ottawa, Canada, Canadian Geodetic Survey, Natural Resources document GGN-18, v. 1.4 .

Eckl, M.C., Snay, R.A., Soler, Tomas, Cline, M.W., and Mader, G.L., 2001, Accuracy of GPS-derived relative positions as a function of interstation distance and observing-session duration: Journal of Geodesy, v. 75, no. 12, p. 633-640. [Also available at http://dx.doi. org/10.1007/s001900100204.]

Environment Canada, 2015, Wateroffice: Government of Canada database, accessed March 15, 2015, at http://wateroffice.ec.gc.ca/.
Federal Emergency Management Agency, 2011, VermontSevere storms and flooding: Federal Emergency Management Agency Preliminary Damage Assessment Report FEMA-1995-DR, accessed February 10, 2015, at http://www.fema.gov/pdf/news/pda/1995.pdf.

GISTutor, 2015, Explaining the differences between ellipsoids, geoids, and topographic elevation: GISTutor, accessed September 28, 2015, at http://www.gistutor.com/concepts/9beginner-concept-tutorials/19-explaining-the-differencesbetween-ellipsoids-geoids-and-topographic-elevation.html.

Howland, W.G., Gruessner, Barry, Lescaze, Miranda, and Stickney, Michaela, 2006, Lake Champlain-Experience and lessons learned brief: Grand Isle, Vt., Lake Champlain Basin Program, p. 93-114.

Huang, Jianliang, and Véronneau, Marc, 2013, Canadian gravimetric geoid model 2010: Journal of Geodesy, v. 87, no. 8, p. 771-790. [Also available at http://dx.doi. org/10.1007/s00190-013-0645-0.]

International Joint Commission, 2013, Plan of study for the identification of measures to mitigate flooding and the impacts of flooding of Lake Champlain and Richelieu River: Ottawa, Canada, and Washington, D.C., International Joint Commission, 128 p. [Also available at http://ijc.org/files/publications/Final_PoS_LakeChamplainRichelieuRiver.pdf.]

Kenney, T.A., 2010, Levels at gaging stations: U.S. Geological Survey Techniques and Methods, book 3, chap. A19, 60 p. [Also available at http://pubs.usgs.gov/tm/tm3A19/.]

Kouba, Jan, and Héroux, Pierre, 2001, Precise point positioning using IGS orbit and clock products: GPS Solutions, v. 5, no. 2, p. 12-28. [Also available at http://dx.doi.org/10.1007/PL00012883.]

Lake Champlain Basin Program, 2013, Flood resilience in the Lake Champlain Basin and Upper Richelieu River: Lake Champlain Basin Program, 93 p. [Also available at http://www.lcbp.org/wp-content/uploads/2013/04/ FloodReport2013_en.pdf.]

Lake Champlain Basin Program, 2015, Lake and basin facts: Grand Isle, Vt., Lake Champlain Basin Program Web page, accessed July 7, 2015, at http://www.lcbp.org/about-thebasin/facts/.

Lake Champlain Land Trust, 2015, Lake Champlain facts: Burlington, Vt., Lake Champlain Land Trust Web page, accessed July 7, 2015, at http://www.lclt.org/about-lakechamplain/lake-champlain-facts/.

Lake Champlain Research Consortium, 2004, About Lake Champlain: Lake Champlain Research Consortium Web page, accessed April 2004, at http://academics.smcvt.edu/ lcrc/aboutlake.html. 
National Geodetic Survey, 2012a, GEOID12A: National Geodetic Survey, National Oceanic and Atmospheric Administration Web page, accessed February 2, 2015, at http://www.ngs.noaa.gov/GEOID/GEOID12A/.

National Geodetic Survey, 2012b, The National adjustment of 2011 project: National Geodetic Survey, National Oceanic and Atmospheric Administration Web page, accessed February 2, 2015, at http://www.ngs.noaa.gov/web/surveys/ NA2011/.

National Geodetic Survey, 2014, Gravity for the redefinition of the American Vertical Datum (GRAV-D): National Geodetic Survey, National Oceanic and Atmospheric Administration Web page, accessed March 15, 2015, at http://www.ngs.noaa.gov/GRAV-D/.

National Geodetic Survey, 2015a, Continuously Operating Reference Station (CORS): National Geodetic Survey, National Oceanic and Atmospheric Administration Web page, accessed February 2, 2015, at http://www.ngs.noaa. gov/CORS/.

National Geodetic Survey, 2015b, OPUS - Online positioning user service: National Geodetic Survey, National Oceanic and Atmospheric Administration Web page, accessed February 2, 2015, at http://www.ngs.noaa.gov/OPUS/about. jsp.

National Geodetic Survey, 2015c, OPUS Projects: National Geodetic Survey, National Oceanic and Atmospheric Administration Web page, accessed February 2, 2015, at http://www.ngs.noaa.gov/OPUS-Projects/OpusProjects. shtml.

National Resources Canada, 2013, Height reference system modernization: Natural Resources Canada, Government of Canada Web page, accessed March 15, 2015, at http://www. nrcan.gc.ca/earth-sciences/geomatics/geodetic-referencesystems/9054.

National Weather Service, 2012, Top 5 weather events of 2011 across the north country — \#2 weather event-Lake Champlain record flooding: Burlington, Vt., National Weather Service, National Oceanic and Atmospheric Administration Web page, accessed February 2015, at http://www.erh.noaa.gov/btv/events/Top5_2011/2.php.

National Weather Service, 2015, Advanced Hydrologic Prediction Service-Lake Champlain at Rouses Point: Burlington, Vt., National Weather Service, National Oceanic and Atmospheric Administration current forecast hydrograph and gage information, accessed May 5, 2015, at http://water.weather.gov/ahps2/hydrograph. php?gage $=$ roun $6 \& w f o=b t v$.
Riboust, Philippe, and Brissette, François, 2015, Climate change impacts and uncertainties on spring flooding of Lake Champlain and the Richelieu River: Journal of American Water Resources Association, v. 51, no. 3, p. 776-793. [Also available at http://dx.doi.org/10.1111/jawr.12271.]

Rydlund, P.H., Jr., and Densmore, B.K., 2012, Methods of practice and guidelines for using survey-grade global navigation satellite systems (GNSS) to establish vertical datum in the United States Geological Survey: U.S. Geological Survey Techniques and Methods, book 11, chap. D1, 120 p. [Also available at http://pubs.usgs.gov/ $\mathrm{tm} / 11 \mathrm{~d} 1 /$.

Shanley, J.B., and Denner, J.C., 1999, The hydrology of the Lake Champlain Basin, in Manley, T.O., and Manley, P.L., eds., Lake Champlain in transition-From research toward restoration: Washington, D.C., American Geophysical Union, p. 41-66. [Also available at http://dx.doi. org/10.1029/WS001p0041.]

Stickney, Michaela, Hickey, Colleen, and Hoerr, Roland, 2001, Lake Champlain Basin Program-Working together today for tomorrow: Lakes \& Reservoirs-Research \& Management, v. 6, no. 3, p. 217-223. [Also available at http://dx.doi.org/10.1046/j.1440-1770.2001.00150.x.]

U.S. Census Bureau, 2015a, Burlington (city), VermontPopulation, 2013 estimate: U.S. Census Bureau, U.S. Department of Commerce State and county quickfacts, accessed July 28, 2015, at http://quickfacts.census.gov/qfd/ states/50/5010675.html.

U.S. Census Bureau, 2015b, Plattsburgh (city), New YorkPopulation, 2013 estimate: U.S. Census Bureau, U.S. Department of Commerce State and county quickfacts, accessed July 28, 2015, at http://quickfacts.census.gov/qfd/ states/36/3658574.html.

U.S. Census Bureau, 2015c, Quickfacts beta-Colchester town, Chittenden County, Vermont—Population, 2013 estimate: U.S. Census Bureau, U.S. Department of Commerce quickfacts, accessed July 28, 2015, at http://www.census.gov/quickfacts/table/ PST045214/5000714875.

U.S. Geological Survey, 2015a, USGS 04294500, Lake Champlain at Burlington, VT: U.S. Geological Survey National Water Information System Web interface, accessed May 5, 2015, at http://waterdata.usgs.gov/nwis/ inventory/?site_no $=04294500$.

U.S. Geological Survey, 2015b, USGS 04295000, Richelieu R (Lake Champlain) at Rouses Point, NY: U.S. Geological Survey National Water Information System Web interface, accessed May 5, 2015, at http://waterdata.usgs.gov/NY/ nwis/uv?site_no $=04295000$. 


\section{Network Global Navigation Satellite System Surveys to Harmonize Datums for the Lake Champlain Basin}

U.S. Geological Survey, 2015c, USGS 04279085, Lake Champlain North of Whitehall, NY: U.S. Geological Survey National Water Information System Web interface, accessed May 5, 2015, at http://waterdata.usgs.gov/nwis/ inventory/?site_no $=04279085$.

U.S. Geological Survey, 2015d, USGS current water data for New York: National Water Information System Web interface, U.S. Geological Survey, accessed March 15, 2015, at http://waterdata.usgs.gov/ny/nwis/rt.

U.S. Geological Survey, 2015e, USGS current water data for Vermont: U.S. Geological Survey National Water Information System Web interface, accessed March 15, 2015, at http://waterdata.usgs.gov/vt/nwis/rt.

Véronneau, Marc, Huang, Jianliang, Smith, D.A., and Roman, D.R., 2014a, Canada's new vertical datum-CGVD2013: xyHT magazine, v. 1, no. 4, p. 43-45. [Also available at http://www.xyht.com/surveying/canadas-new-verticaldatum-cgvd2013/.]

Véronneau, Marc, Huang, Jianliang, Smith, D.A., and Roman, D.R., 2014b, CGVD2013, part 2: xyHT magazine, v. 1, no. 5, p. 41-43. [Also available at http://www.xyht.com/ surveying/cgvd2013-part-2-2/.] 


\section{Appendixes}

[Available for download at http://dx.doi.org/10.3133/sir20165009.] 


\section{Appendix 1. Global Navigation Satellite System Data Collection Information for All Benchmarks Surveyed in the Harmonization of American and Canadian Datums}

As a ZIP file, appendix 1 includes Global Navigation Satellite System vertical benchmark and static observation forms for the following locations:

- St. Lawrence River at Sorel, Quebec, Canada

- Richelieu River at Saint-Ours dam at Saint-Ours, Quebec, Canada

- Richelieu River at Fryers Dam at Chambly, Quebec, Canada

- Richelieu River at Saint-Jean-sur-Richelieu, Quebec, Canada

- Richelieu River at Saint-Paul de l'Île aux Noix, Quebec, Canada

- Lake Champlain at Philipsburg, Quebec, Canada

- Richelieu River (Lake Champlain) at Rouses Point, New York, United States

- Lake Champlain at Burlington, Vermont, United States

- Lake Champlain north of Whitehall, New York, United States

The name of a file indicates the location name in shortened form, document type ("vb" for vertical benchmark, "so" for static observation, and "sl" for survey log forms), and date (for example, "sorel_vb_04_15_2015.pdf" is a vertical benchmark form for the St. Lawrence River at Sorel, dated April 15, 2015).

Appendix 1 is available for download at http://dx.doi.org/10.3133/sir20165009. 


\section{Appendix 2. Final Coordinates as Determined in and From the Online Positioning User Service Projects Least-Squares Adjustment for Harmonization of the American and Canadian Datums}

The National Geodetic Survey Online Positioning User Service (OPUS) Projects network adjustment report on the final coordinates in the harmonization of the American and Canadian datums is available for download at http://dx.doi.org/10.3133/sir20165009.

Information about OPUS outputs is available at

http://www.ngs.noaa.gov/faq.shtml and http://www.ngs.noaa. gov/OPUS/about.jsp\#FAQ. 


\section{Appendix 3. Surveyor Leveling Information for Sites With Benchmarks That Could Not Be Surveyed Directly by Using Global Navigation Satellite Systems in Harmonization of the American and Canadian Datums}

Appendix 3, as a ZIP file, includes gage level notes for the following locations and dates:

- Richelieu River at Saint-Jean-sur-Richelieu, Quebec, Canada; April 14, 2015

- Richelieu River at Saint-Paul de l'Île aux Noix, Quebec, Canada; April 14, 2015

- Lake Champlain at Burlington, Vermont, United States; April 13 and May 13, 2015

- Lake Champlain north of Whitehall, New York, United States; April 14 and May 14, 2015

Appendix 3 is available for download at http://dx.doi.org/10.3133/sir20165009. 


\section{Appendix 4. Elevation Offset Information for Benchmarks Surveyed Directly by Using Global Navigation Satellite Systems in Harmonization of the American and Canadian Datums}

This spreadsheet contains the calculations for determination of elevation differences for the reference marks and survey control disks at the nine Global Navigation Satellite System (GNSS) survey locations based on the results of the Online Positioning User Service Projects network adjustment report:

- St. Lawrence River at Sorel, Quebec, Canada

- Richelieu River at Saint-Ours dam at Saint-Ours, Quebec, Canada

- Richelieu River at Fryers Dam at Chambly, Quebec, Canada

- Richelieu River at Saint-Jean-sur-Richelieu, Quebec, Canada

- Richelieu River at Saint-Paul de l'Île aux Noix, Quebec, Canada

- Lake Champlain at Philipsburg, Quebec, Canada

- Richelieu River (Lake Champlain) at Rouses Point, New York, United States

- Lake Champlain at Burlington, Vermont, United States

- Lake Champlain north of Whitehall, New York, United States

The spreadsheet shows the results of four types of conversion:

- from current [2015] elevation to GNSS network adjustment elevation (either in the North American Vertical Datum of 1988 [NAVD 88] or the National Geodetic Vertical Datum of 1929 [NGVD 29]):

current elevation [NAVD 88 or NGVD 29] - GNSS network adjustment elevation [NAVD 88 or NGVD 29]
- from current elevation in Canadian Geodetic Vertical Datum of 2013 (CGVD2013) to GNSS network adjustment elevation in NAVD 88:

$$
\text { NAVD } 88 \text { - CGVD2013 }
$$

Table 4-1 lists the abbreviations used in the spreadsheet. Appendix 4 is available for download at http://dx.doi.org/10.3133/sir20165009.

Table 4-1. Abbreviations used in the spreadsheet of calculations for determining elevation differences in the harmonization of the American and Canadian datums.

\begin{tabular}{ll}
\hline Abbreviation & \multicolumn{1}{c}{ Definition } \\
\hline BM & benchmark \\
CGVD2013 & Canadian Geodetic Vertical Datum of 2013 \\
CGVD 28 & Canadian Geodetic Vertical Datum of 1928 \\
$\mathrm{ft}$ & foot \\
GNSS & Global Navigation Satellite System \\
GPS & Global Positioning System \\
m & meter \\
NAVD 88 & North American Vertical Datum of 1988 \\
NGVD 29 & National Geodetic Vertical Datum of 1929 \\
NY & New York \\
OPUS & Online Positioning User Service \\
RM & reference mark \\
RP & reference point \\
USCG & U.S. Coast Guard \\
USGS & U.S. Geological Survey \\
VT & Vermont \\
WS & water surface \\
\hline
\end{tabular}

- from current elevation in NGVD 29 to GNSS network adjustment elevation in NAVD 88 :

$$
\text { NAVD } 88 \text { - NGVD } 29
$$

- from current elevation in Canadian Geodetic Vertical Datum of 1928 (CGVD 28) to GNSS network adjustment elevation in NAVD 88:

$$
\text { NAVD } 88 \text { - CGVD } 28
$$



For more information concerning this report, contact: Director, New England Water Science Center U.S. Geological Survey 331 Commerce Way, Suite 2

Pembroke, NH 03275

dc_nweng@usgs.gov or visit our Web site at: http://newengland.water.usgs.gov

Publishing support by: The Pembroke and Rolla Publishing Service Centers. 


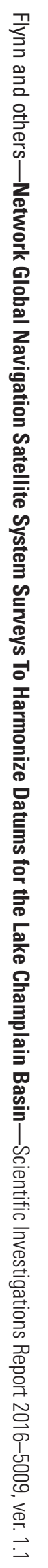

